\title{
THE IMPACT ANALYSIS OF DRINA REGATTA MANAGEMENT ON THE SERBIAN REGIONAL DEVELOPMENT
}

UDC: 338.48:005(497.11)

Original Scientific Paper

\author{
Marija NAJDIĆ ${ }^{1}$, Tamara LUKIĆ ${ }^{2}$ \\ ${ }^{1}$ The College of Tourism, 11070 Belgrade, Blvd Zorana Đinđića 152-a, Republic of Serbia \\ E-mail: marija.najdic@gmail.com \\ ${ }^{2}$ Singidunum University, 11000 Belgrade, Danijelova 32, Republic of Serbia
}

Paper received: 31.10.2016.; Paper accepted: 28.11.2016.

\begin{abstract}
The purpose of this analysis is the indication of proper management in organization of a tourism event in the open space which requires detailed planning and strong coordination of all participants. This paper presents the tourism offer of Western Serbia, with special emphasis on Drina regatta race, a sports manifestation which has been organizing in the passed 24 years. The authors gave a review of the relevant official reports from Ljubovija Tourism Organization, along with complementary SWOT analysis of the environment given in the Strategy for local sustainable development of Ljubovija Municipality for 2013-2022. The authors also pointed out the importance of constant improvement of the tourism offer and complementary services that management team must coordinate and overview. Special attention was given in the determination of budget funds and their allocation in the organization of one of the biggest regatta in the Balkans. By bringing up the quality of services at higher level with the inclusion of rescue services and pointing out the importance of preserving the nature, local management succeeded in exceeding expectations of guests and local residents. Proper management resulted in increased number of guests who use registered accommodation facilities in the Municipality of Ljubovija for the observed years.
\end{abstract}

Keywords: Management, Drina regatta, Organization, Tourism, Serbia.

\section{INTRODUCTION}

Today's society is known for rapid change, new technologies and new ways of doing business. James Reed, General Manager of European employment agencies pointed out that in this new world the winners will be those who attract the most talented individuals, who are the most astute and ones who transform the way we do business in order to make the right and constant value to consumers...(Hartli, 2007).

Contribution of tourism to economic prosperity depends on the quality and the advent of the tourist offer, (UNWTO, 2015). Tourism development represents differentiation of touristic offer along with permanent growth of service quality and should be followed by appropriate marketing efforts. New ways of satisfying customers' requirements as well as improving quality aspects of a touristic product are essential for further development of tourism on the global level (Đorđević et al., 2016).

According to the Strategy of local sustainable development of the Municipality of Ljubovija for the period 2013- 2022 (Strategy..., 2013), particularly for its importance, stands out that the tourism sector should be encouraged to create offers that will be in line with the concept of the future development of Ljubovija. With respect to the principles of sustainable development of the Municipality of Ljubovija, the following forms of tourism were defined: rural, camping, recreational, educational programs with exploring, hunting, fishing, cultural manifestation, nautical and cycling tourism. In addition, there are also protected areas, which in the territory of Ljubovija are a few, and represent a special tourism benchmark of the region and a significant comparative advantage (Memorial Mačkov stone, canyon Trešnjica River, area of Tornik Bobija). Bike and jeep route 
connect three municipalities: Loznica, Krupanj and Ljubovija. Officially, there are 19, they are all classified, relatively easily accessible and properly signposted.

The major part of route is in the Municipality of Ljubovija . Routes are practically traced and can be used in whole or in part by pedestrians, hikers and ATVs (Terrain Vehicles). Paragliding airfields are generally on TorničkaBobija at about 1,279 meters above sea level. Thus, the model form is applicable to the entire territory of Serbia and depending on the specific locations, it can be modified. The form depends on the trip duration and time distance between the two stops and their total number. The proposed model has two goals: to introduce tourists with Serbian villages, and to create a basic knowledge for local people about potential earnings from tourism activity (Strategy..., 2013).

Imai (2008) emphasizes: "Quality is managers' responsibility. Poor quality is the result of poor management". As a successful and recognizable on the tourism market in providing of quality offer for tourists as well as the participants of the event, Drina traditional regatta was this year's winner of the „Tourism flower” in the category for „Best Event" by the Tourism Organization of Serbia (Drinska regata, 2016). Parameters that were taken into valorization included program quality and content of the offer, the number of visitors and achieved marketing activities in the field of promotion. The event is organized every year in July for a period of 4 to 5 days with the purpose of improving and promoting tourism activities and tourism attractions of the National Park Tara, Drina and BajinaBasta, which are located in Western Serbia. The organizer of the regatta is Sports and tourism center „Bajina Basta”, the Municipality of Ljubovija and the Ljubovija Tourism Organization.

Managing a regatta or any kind of an event that takes place at specific time of the year, particulary in the open space, takes a high risk. This is an acitivity which must take into consideration all factors that might have influence on phases of preparation, realization and end result, and many of those factors are intangible and unpredictable.

Studies on the factors that contribute to business performance of the organization have shown a positive relationship between strategic planning and business results (Bowman and Helfat, 2001). Therefore, in an attempt to systematically monitor the results, the objectives were defined and given in the local Strategy (Strategy..., 2013):

- Enriching and upgrading the quality of tourism offer,

- Setting up tourism informative promotional activities, organizing events,

- Improvement and promotion,

- Promotion of tourism in the municipality,

- Participation in the development and implementation of tourism policy,

- Improving the conditions for welcoming and accommodating tourists.

The development plans increasingly give importance to environmental protection as a priority and a direction in which tourism demand should be pointed to. The Serbian Ministry of Environment provided nearly one billion dinars for action „Clean Serbia“ and directed them to the Serbian municipalities. The main task was to remove waste, followed by the establishment of management for waste management, and the creation of eco-industries and recycling centers. The importance of this subject was also seen in the result of a recent survey conducted by Expedia, in the case of the hotel industry. The survey has showed that more than 75 percent of the 5,000 respondents were interested in ways how sustainability efforts have contributed to their tourism experience, and how they can contribute and help in preserving the environment (Jayawardena and Miththapala, 2013). Therefore managing communication with the tourists and pointing out the necessity of responsible behavior towards the natural environment brings the need for creativity in organizing various activities in which tourists would take part, for example „To raise environmental awareness" campaign which involves a significant number of volunteers who highlight the importance of preserving nature and the environment along with the proper disposal of waste.

\section{TOURISM OFFER OF LJUBOVIJA}

Tourism Organization of Ljubovija is constantly making efforts to promote its natural beauty, and also through the organization of cultural events each year, bring together a large number of people who love the Drina River. The site of tourism organizations display the entire offer and events to visit in this part of Serbia, and they are: the Drina River, mountain Bobija, the Trešnjica River, canyon Trešnjica, Mačkov stone, caves Kačar and 
Zvečaljka; a wooden church, the church in Selance,the church in Ljubovija, Ljubovija church, the church in Gračanica, the church in Arsenović, Savković church, the church in Caparić, Vrhpolje Church, a church in Orovička mountain, monastery „Saint Nikolaj Serbian”, Soko Grad, Monastery „Saint Trinity”- Čitluk, Monastery dedicated to the Holy Mother in Rujevac, recreational tourism, fishing, hunting, hiking, biking, International gastro festival Drina „Gastrofest”, ,Drina Regatta” Ljubovija (Turistička organizacija Ljubovija, 2016).

Also it should be noted that Soko Grad has made the monastery complex within which the annual event „Moba” - a meeting of young people from the diaspora, as well as many other cultural events take place.

As an integral part of the tourism offer since 2007, there has been the music festival „The Most Fest”, which brings together the best bands from the former Yugoslavia. Also, additional tourism activities are organized in basketball tournaments, chess tournament, followed by showcase of raspberry products „Malinijada”, theater plays, etc.

Considering that many strategies have failed without a careful defining of the main goals and without the necessary analysis of external and internal environment (Dess et al., 2007), this paper analyzes informations relating to the environmental offer of Ljubovija Municipality, as well as the data related to the internal management of Drina regatta, analysis of financial parameters and their distribution, according to the planned and defined budget.

\section{RESEARCH METHODS}

According to the objective of this research, the method of quality analysis was applied on reports from the Tourism Organization of Ljubovija, with special emphasis on the analysis of the allocation of revenues and expenses during the organization the Drina regatta. This was supplemented with SWOT analysis, within the framework of the local Strategy (Strategy..., 2013), in order to identify which factors in external environment affect management organization of Drina regatta. Finally, we proposed guidelines for further development and improvement of the tourism offer quality in order to improve the tourism competitiveness of the western region of the Republic of Serbia.
In the analysis of Drina regatta management we were guided by the strategies made by Michael Porter for achieving a competitive advantage in the tourism market. The first is a Cost leadership Strategy, based on the creation of low-cost position in relation to competitors. The second is Differentiation Strategy, and that means creating products that are unique and valued by customers. The third is the Focus Strategy, which directs attention to the limited product lines, segments of consumers, or geographic target markets (Porter, 1996).

\section{SWOT ANALYSIS OF THE ECONOMIC ENVIRONMENT: LJUBOVIJA MUNICIPALITY}

SWOT analysis is a general tool designed to be used in the preliminary stages of decision-making and as a precursor to strategic planning in various kinds of applications (Johnson et al., 1989; Bartol et al., 1991). Thus, to determine future plans of a development in the region of Ljubovija, we included SWOT analysis, see Table 1.

Table 1shows that main strenghts of Ljubovija area are: natural resources, tradition in the foodprocessing industry, educational management in the minicipality and SMEs, support of the local governments and presence of foreign investments in exploitation of natural resources.

Existence of elements that are not in favour of Ljubovija economic development should be, if possible, predicted and minimized or eliminated. These threats refer to: natural disasters, unpredictability of prices of agricultural products, bank loans to SMEs, unstable business conditions and regulations due to the global economic crisis.

Detecting the weaknesses is essential in order to set up new goals an directions for development. A proper management in the government organizations should plan opportunities and work on their realization constantly. Therefore, weaknesses that should be turned into opportunities are: creation of a new job places for the residents by attracting investors who would invest in existing industrial zone and in renewable energy facilities, in production of organic food, etc. Local management organizations should also apply for funding through projects and enhance crossborder cooperation with other stakeholders. 
By organizing events that gather local residents as well as international tourists, Ljubovija tourism organization could improve economic state and enhance further development of the Western Serbia region.

\section{Table 1: SWOT analysis of the economic environment of Ljubovija Municipality}

\begin{tabular}{|c|c|}
\hline STRENGHTS & WEAKNESSES \\
\hline $\begin{array}{l}\text { - Natural Resources } \\
\text { - Water potential } \\
\text { - Forest potential } \\
\text { - Agricultural land } \\
\text { - Ore potential } \\
\text { - Existence of relevant policy documents } \\
\text { • Knowledge and experience in the field of agriculture } \\
\text { and food-processing industry } \\
\text { - Professional and trained staff in the municipal } \\
\text { administration issues of the SME sector } \\
\text { - Willingness of local governments and political will for } \\
\text { Economic Development } \\
\text { - Positive examples of foreign investments (The mine } \\
\text { „VelikiMajdan“) }\end{array}$ & $\begin{array}{l}\text { - Undeveloped Industry and Entrepreneurship } \\
\text { - High unemployment rate } \\
\text { - Insufficient use of water potential } \\
\text { - Poor road infrastructure and outdated electrical grid in } \\
\text { rural areas } \\
\text { - A low birth rate and population migration, especially } \\
\text { of highly qualified staff, as well as the departure of } \\
\text { young people from villages to cities } \\
\text { - Distance from the large industrial centers } \\
\text { - Unsolved legal-property relations } \\
\text { - Insufficient number of enterprises } \\
\text { - Work in grey zone } \\
\text { - Lack of motivation of entrepreneurs and farmers to the } \\
\text { wider business merger } \\
\text { - Lack of communication of public and business sectors } \\
\text { - Lack of entrepreneurial spirit } \\
\text { - Fragmentation of land in agriculture }\end{array}$ \\
\hline OPPORTUNI' & THREATS \\
\hline $\begin{array}{l}\text { - Potential for investment in tourism } \\
\text { - Potential for investment in renewable energy (mini } \\
\text { hydro power plants) } \\
\text { - Creation of facilities for simultaneous production of } \\
\text { electricity and heat (green energy production) } \\
\text { - Existence of funds / programs for underdeveloped } \\
\text { border areas (Government of Serbia, donors) } \\
\text { - Attracting investors in existing industrial zone } \\
\text { - Existence of funds for cross-border cooperation (IPA) } \\
\text { - Initiative for a better organization of farmers } \\
\text { - Subsidies to agriculture by the state } \\
\text { - Potential for the production of organic food } \\
\text { - Applying for funding through projects }\end{array}$ & $\begin{array}{l}\text { - Natural disasters (floods from the Drina River and } \\
\text { Ljubovija, landslides, droughts, fires) } \\
\text { - Construction of water facilities upstream of the village } \\
\text { of Ljubovija } \\
\text { - Unpredictability of prices of agricultural products } \\
\text { - Unfavorable credit to companies } \\
\text { - Unstable business conditions (policy, poverty) } \\
\text { - Frequent changes in regulations / conditions of } \\
\text { business } \\
\text { - Slow decentralization } \\
\text { - Continuation of the global economic crisis }\end{array}$ \\
\hline
\end{tabular}

\section{QUALITATIVE ANALYSIS OF THE DRINA REGATTA ORGANIZATION}

The Drina Regatta is known to be the largest regatta in the Balkans with a sailing route of $40 \mathrm{~km}$ (about 9 hours for sailing, which begins in Rogačica and ends in Ljubovija). The race has over 1,300 vessels and over 12,000 participants. Each year it hosts more than 100,000 visitors from all over the world. It is the highest broadcast media manifestation in which all national televisions and many regional and local televisions participate, as well as many newspapers and numerous on-line portals.

Significant benefits of organizing the Drina regatta are multiple and include the promotion of Western Serbia on the international tourism market, a gathering of local population and encourage the return to nature through participation in the regatta, gathering in outdoor activities, concerts, tastings of local domestic products, etc. Revenues of these planned activities are shown in Table 2 (see also Figure 1) and both refer to the year 2013.

It could be noted that the most significant part of the revenue that this event makes is achieving and maintaining sponsorships and organizing the concerts with a total share of over 80 percent in the structure of revenues. Rental space contributes with 16 percent, while revenues from compulsory insurance totaled 1 percent. Under the „Space renting" enter fees that are related to income from the lease of space for food and drink, revenue for the use of public space during the Drina regatta and space for the amusement children park. 
Table 2: Manifestation Incomes in 2013.

\begin{tabular}{|l|r|}
\hline Manifestation Incomes & \multicolumn{1}{|c|}{ In RSD } \\
\hline Sponsorships & 1.612 .000 \\
\hline Space renting & $639.500,00$ \\
\hline Concert tickets & 1.656 .000 \\
\hline Insurance & $49.300,00$ \\
\hline
\end{tabular}

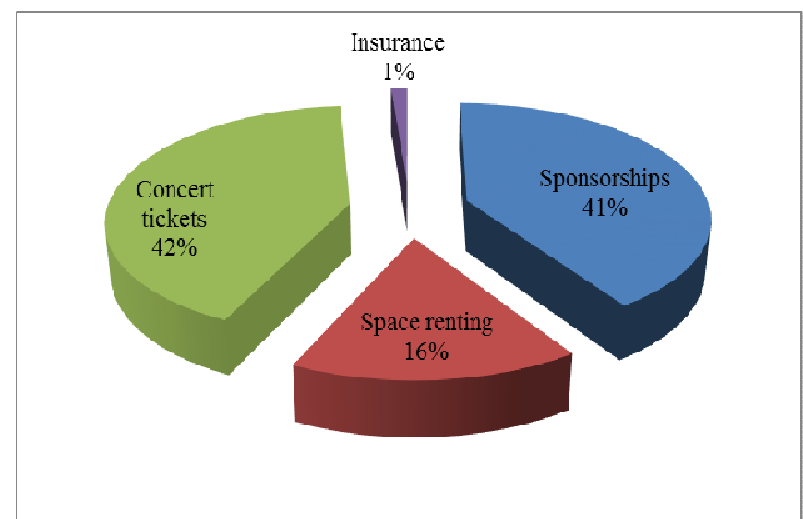

Figure 1: Manifestation Incomes in 2013.

In terms of expenses that occurred during the organization of the Drina regatta in 2013, the largest share was for one-time compensation for concert performers and expenses that have been shown as „Other” (making promotional t-shirts, caps, installation and disassembly of advertising boards, fireworks, printing pendants and numbers for racing boats, renting the plots of land for the regatta, the cost of performers transport, nights and food for journalists, advertising services via the radio and making a commercial, promotional downhill for the press representatives, etc.). Renting the stage with audio and video equipment, setting-up, lighting, etc. have 13 percent share in total expenses for 2013, as shown in Table 3 (see also Figure 2).

Table 3: Manifestation Expenses in 2013.

\begin{tabular}{|l|r|}
\hline Manifestation Expenses & \multicolumn{1}{|c|}{ In RDS } \\
\hline Renting the stage and equipment & $1.243 .000,00$ \\
\hline Personal and Property Insurance & $984.960,00$ \\
\hline Musicians Performance & $2.328 .000,00$ \\
\hline Stewarding Services & $595.000,00$ \\
\hline Other & $4.753 .397,00$ \\
\hline
\end{tabular}

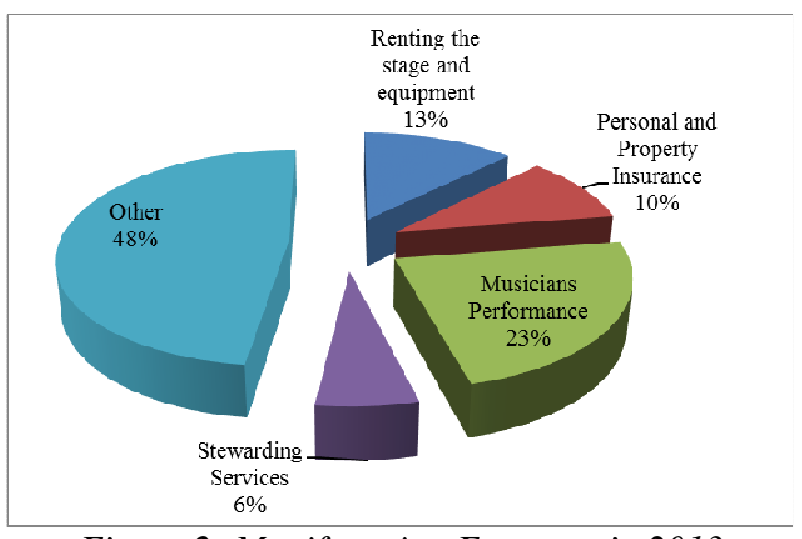

Figure 2: Manifestation Expenses in 2013

By analyzing the allocation of funds in 2015 , we can see that the expenses are more than doubled for renting the stage with necessary equipment with a total share of 48 percent of total expenditures. This could be explained with renting higher quality equipment in addition of better lighting and technical elements. For the year 2015, a new categories were introduced such as services for providing accommodation and beverage which together accounted for 12 percent of total expenditures in the organization of the regatta. It can also be noted that the costs of insurance safety of property and individuals were particularly singled out, which amounted to 8 percent of total expenditures. Cost allocation is shown in Table 4 (see also Figure 3).

Table 4: Manifestation Expenses in 2015.

\begin{tabular}{|l|r|}
\hline Manifestation Expenses & \multicolumn{1}{|c|}{ In RDS } \\
\hline Renting the stage and equipment & $2.900 .000,00$ \\
\hline Personal and Property Insurance & $472.800,00$ \\
\hline Accommodation Services & $387.915,00$ \\
\hline Beverage & $309.629,00$ \\
\hline Other & $1.944 .536,00$ \\
\hline
\end{tabular}

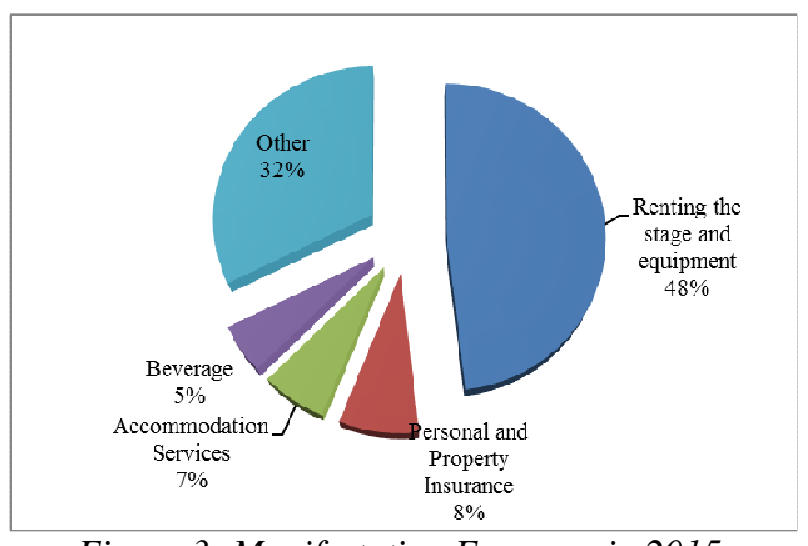

Figure 3: Manifestation Expenses in 2015.

Consumers are certainly in the center of trade; the integral management process in the store at the 
macro and micro level of its functioning starts and ends with customers (Lovreta et al., 2009). Organizing events in nature consequently brings need for prediction of all factors that can otherwise be found in the plans for conventional spaces such as weather conditions, increased safety of guests and participants of the regatta, additional temporary space arrangement and rescue services on the river. As shown in Table 5, in 2016 the most investment 42 percent were allocated in "Other" (the broadcasting of advertisements on radio stations, compensation to owners of land on the start of the regatta, the lease of land at the finish of the regatta, regattas services for recording and broadcasting, accommodation and food for guests and a stewards service, etc.). Followed by the costs in the form of fees for performers in 25 percent, renting the stage with equipment and services rescue services with 12 percent (together for a total of 24 percent), and finally the cost of renting boats services for VIP guests with 9 percent share in total expenditures (see also Figure 4).

\section{Table 5: Manifestation Expenses in 2016.}

\begin{tabular}{|l|r|}
\hline Manifestation Expenses & \multicolumn{1}{|c|}{ In RDS } \\
\hline Musicians Performance & $1.221 .674,00$ \\
\hline Safeguard Services & $588.000,00$ \\
\hline Renting the stage and equipment & $580.000,00$ \\
\hline Boat rental for VIP guests & $459.880,00$ \\
\hline Other & $2.077 .481,00$ \\
\hline
\end{tabular}

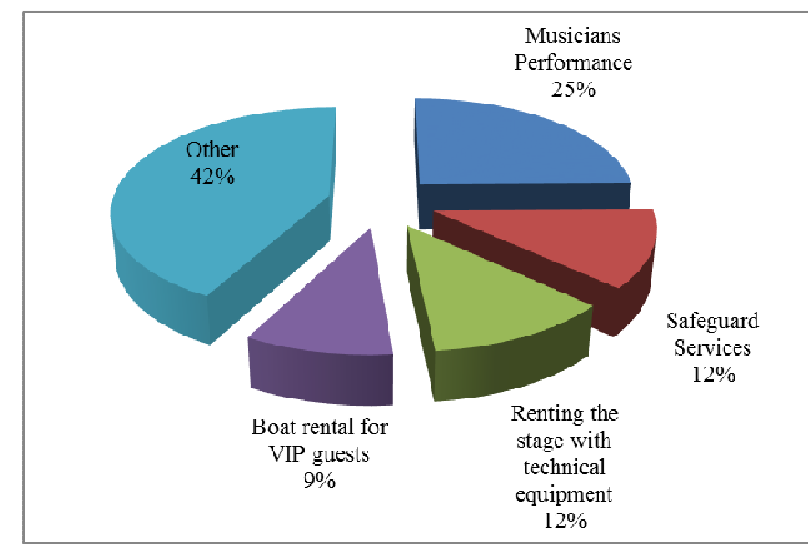

Figure 4: Manifestation Expenses in 2016.

When we look at the structure of guests in 2012, we note that the visit of domestic guests from the Republic of Serbia is significantly higher compared to the foreign guests with over 90 percent participation in the use of accommodation services. It is also noticeable that more tourists choose a hotel accommodation facilities, 71 percent of them, compared to 29 percent who favored accommodation in rural households.
Structure of the guests in relation to the structure of accommodation is shown in Figure 5.

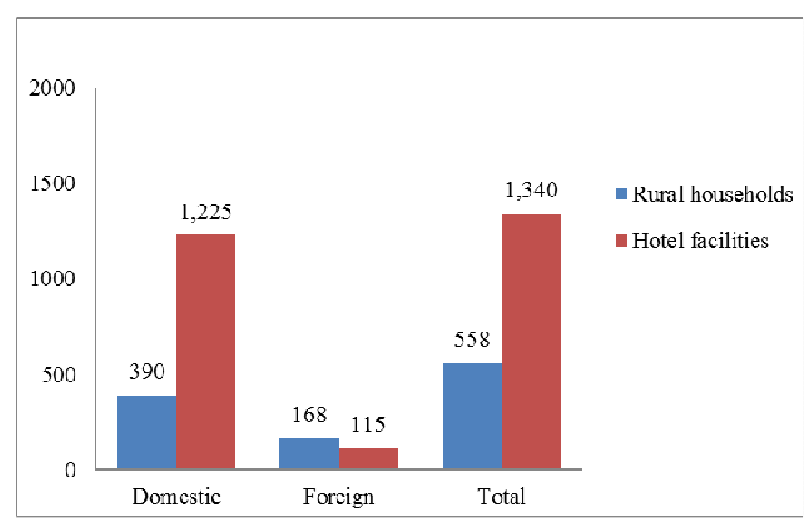

Figure 5: Accommodation and guest structure in 2012.

In the following year, 2013, the number of domestic tourists increased significantly, by approximately one third and amounted to a total of 2,360 guests. In terms of selecting the type of accommodation, considerably noticeable increase was in accommodation in rural households who participated with 47 percent against hotels accommodation which had a 53 percent occupacy, as shown in Figure 6.

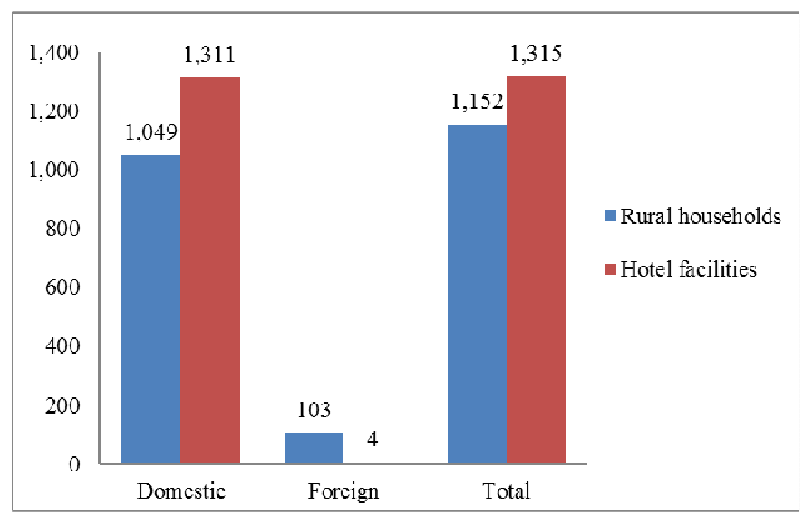

Figure 6: Accommodation and guest structure in 2013.

From year to year, the organization of the regatta shows constant improvement, primarily in quality of tourism offer, which leads to an increase in volume of job places. With an introduction of a new services and outdoor free activities, along with the possibility to participate in the regatta race, introducing new ways of waste disposal, upgrading raising security measures, dealing with the promotion of an event throughout the year, the number of the participants increased for 20 percent in 2016 compared to 2015. 
Accordingly, it can be said that the following aspects are decisive as regards to international competitive capacity of domestic economy: human resources including skills, resources and effectiveness of using natural resources, physical capital, which also depends on the level of development and effectiveness of using technical knowledge, efficiency of social and economic system including economic policy, (Kefela, 2010).

It is expected that the next Drina regatta which will be held from 19 to 23 July 2017 will be even greater in number of participants and guests who will stay for several days and will be accommodated in the registered accommodation facilities.

\section{CONCLUSIONS AND IMPLICATIONS}

When planning special events that are going to be held each year, it is necessary to have in mind the consistency in the quality of supply chain in order to meet the expectations of both tourists and participants of the event.

Creating satisfied customers, and thus future sales, requires that customers continue to believe that the brand meets their needs and offer superior value when they use it. Companies must deliver as much value as customers initially expected, and it must be enough to satisfy their needs (Hawkins et al., 2004).

The assumption is that proactive management should not only meet tourist's expectations but overcome them in order to create unique experiences that would contribute to their loyalty.

Some of the measures to improve the quality of the organization of the regatta will be reflected through the plan of expansion of parking spaces in the motel area, setting the visible signalization points in the camp and on the boats, the introduction of ecological vehicles - boats for disposal of waste in order to minimize pollution of the Drina River, engaging enough promoters of the regatta that will promote an event over the year, to expand cooperation with other tourism organizations, etc.

One of the proposals of the management group was that other sports events, in addition to regatta race boats, should not be organized in the framework of Drina regatta, but within the year, which would acquire larger financial investment. Further recommendations are that cultural and entertainment events on water should be better developed (engaging trumpet orchestras, miss pageant regatta, selection of the most original crew, competition in water jumping, etc.).

\section{REFERENCES}

Bartol, K. M., \& Martin, D. C. (1991). Management. New York: McGraw Hill, Inc.

Građane ekologija skoro da i ne interesuje. (2011). Blic. Retrieved from http://www.blic.rs/vesti/drustvo/gradane-ekologijaskoro-da-i-ne-interesuje/92vz50r

Bowman, E.H., \& Helfat, C.E. (2001). Does Corporate Strategy Matter? Strategic Management Journal, 22(1), 1-23.

Dess, G. G., Lumpkin, G. T., \& Eisner, A. B.(2007). Strategijski menadžment. Beograd: Data Status.

Đorđević D., Bogetić S., Ćoćkalo D., \& Lekić N. (2016). The analysis of directions for improvement of competitiveness in domestic hotel enterprisesstudents attitudes. Journal of Engineering Management and Competitiveness (JEMC), 6(1), 311.

Jayawardena, C., \& Miththapala, S. (2013, 03.04.2013). Maslow's Hierarchy through tourists' eyes. eTurboNews.

Hartli, Dž. (2007). Kreativne industrije. Beograd: Clio.

Hawkins, D. I., Best, R. J., \& Coney, K. A.(2004). Consumer Behavior: Building Marketing Strategy (9th ed.). NY: McGraw-Hill/Irwin.

Johnson, G., Scholes, K., \& Sexty, R. W. (1989). Exploring strategic management. Scarborough, Ontario: Prentice Hall.

Kefela, G. T. (2010). Knowledge-based economy and society has become a vital commodity to countries. International NGO Journal, 5(7), 160-166.

Lovreta, S., Manić, E., \& Stojković, D. (2009). Model for Managing Trade Policy in Cerating Modern Market Economy. Paper presented at the International Conference "Economic Policy and Global Recession", Belgrade.

Masaaki, I. (2008). Kaizen. Beograd: Mono iManjana.

Porter, M., E. (1996). What is strategy. Harvard business Review, 74(6), 61-78.

Drinska regata. Retrieved 20.10.2016, from http://regata.rs/

Strategija lokalnog održivog razvoja opštine Ljubovija za period od 2013-2022. (2013). Ljubovija: Opština Ljubovija Retrieved from http://www.ljubovija.rs/dokumenta/SLOR.pdf., 3436.

Turistička organizacija Ljubovija. Retrieved 20.10.2016, from http://www.tolj.rs. UNWTO. Tourism Highlights (2015 ed.). 


\section{ANALIZA UTICAJA ORGANIZACIJE DRINSKE REGATE NA REGIONALNI RAZVOJ SRBIJE}

Svrha ove analize je ukazivanje na pravilan menadžment u organizovanju turističkog događaja na otvorenom prostoru, koji zahteva detaljno planiranje i jaku koordinaciju svih učesnika. U radu je predstavljena turistička ponuda zapadne Srbije sa posebnim osvrtom na Drinsku regatu, sportsku manifestaciju koja se organizuje proteklih 24 godine. Autori su dali pregled relevantnih zvaničnih izveštaja Turističke organizacije Ljubovija, kao i komplementarnu SWOT analizu šireg okruženja prikazanu u Strategiji lokalnog održivog razvoja opštine Ljubovija za period od 2013- 2022. godine. Autori su takođe istakli značaj konstantnog unapređenja turističke ponude i komplementarnih usluga koje menadžment tim mora da koordinira i nadgleda. Posebna pažnja je data utvrđivanju raspodele budžetskih sredstava u organizaciji jedne od najvećih regata na Balkanu. Podižući kvalitet usluga na veći nivo, kroz uvođenje službe za spašavanje i ukazivanje na značaj očuvanja prirode, lokalni memadžment tim je uspeo da prevaziđe očekivanja turista i lokalih gostiju. Pravilan način organizacije Drinske regate je rezultirao povećanjem broja gostiju u registrovanim smeštajnim objektima opštine Ljubovija za posmatrane godine.

Ključne reči: Menadžment, Drinska regata, Organizacija, Turizam, Srbija. 